\title{
Molecular analysis and expression of the extracellular lipase of Aeromonas hydrophila MCC-2
}

\author{
Yin Ching Chuang, ${ }^{1}$ Shu Fen Chiou, ${ }^{2} \dagger$ Jer Horng Su, ${ }^{2} \neq$ Mei Li Wu $\$$ \\ and Ming Chung Chang ${ }^{2}$
}

Author for correspondence: Ming Chung Chang. Tel: +8866 2754697. Fax: +88662754697.

e-mail: s5883105@sparc2.cc.ncku.edu.tw

\footnotetext{
1 Division of Infectious Diseases, Department of Internal Medicine, National Cheng Kung University Medical College and University Hospital, Tainan, Taiwan, Republic of China

2 Department of Biochemistry, Medical College, National Cheng Kung University, Tainan, Taiwan, Republic of China
}

The structural gene encoding the extracellular lipase of Aeromonas hydrophila MCC-2 was cloned and found to be expressed in Escherichia coli using its own promoter. When the cloned gene (lip) was expressed in E. coli minicells, an $80 \mathrm{kDa}$ protein was identified. Subcellular fractionation of $E$. coli carrying the lip gene indicated that the Lip protein was mainly associated with the membrane fraction. Nucleotide sequence analysis revealed that the gene is $2253 \mathrm{bp}$ long, coding for a $79.9 \mathrm{kDa}$ protein with an estimated pl of 10.36. The deduced protein contains two putative signal peptide cleavage sites; one is a typical signal peptidase cleavage site and the other bears a strong resemblance to known lipoprotein leader sequences. Radioactivity from [ $\left.{ }^{3} \mathrm{H}\right]$ palmitate was incorporated into the Lip protein when expressed in E. coli. The deduced protein contains a sequence of VHFLGHSLGA which is very well conserved among lipases. It shows $67 \%$ and $65 \%$ overall identity to the amino acid sequences of lipase from A. hydrophila strains H3 and JMP636, respectively, but shows little homology to those of other lipases. The Lip protein was purified to homogeneity from both $A$. hydrophila and recombinant $E$. coli. In hydrolysis of p-nitrophenyl esters and triacylglycerols, using purified enzyme, the optimum chain lengths for the acyl moiety on the substrate were $C_{10}$ to $C_{12}$ for ester hydrolysis and $C_{8}$ to $C_{10}$ for triacylglycerol hydrolysis.

Keywords: lipase, Aeromonas bydrophila, lipoprotein

\section{INTRODUCTION}

The Gram-negative bacteria belonging to the genus Aeromonas are ubiquitous, waterborne microorganisms that have been recognized with increasing frequency as human and fish pathogens. Several reports have implicated Aeromonas species, particularly A. bydrophila, as a cause of intestinal and extraintestinal infections in humans (Agger et al., 1985; Figura et al.,

\footnotetext{
†Present address: Department of Marine Resources, National Sun-Yat-Sen University, Kaohsiung, Taiwan, Republic of China.

$\ddagger$ Present address: Department of Industrial Safety and Hygiene, Chia-Nan College of Pharmacy and Science, Tainan, Taiwan, Republic of China.

Present address: Department of Food Science and Technology, National Pingtung Polytechnic Institute, Pingtung, Taiwan, Republic of China.

The GenBank accession number for nucleotide sequence data reported in this paper is U63543.
}

1986; Janda \& Duffey, 1988; Altwegg \& Geiss, 1989; Mikhail et al., 1990; Namdari \& Bottone, 1990; Ko \& Chuang, 1995). The exact mechanism for the pathogenesis of $A$. bydrophila is not presently understood. Several potential virulence factors such as enterotoxins (Burke et al., 1981; Asao et al., 1984; Rose et al., 1989), haemolysins (Johnson \& Lior, 1981; Kuijper et al., 1989), cytotoxic proteins (Lawson et al., 1985), a surface protein (Dooley et al., 1988) and flexible pili (Ho et al., 1990) related to the pathogenicity of $A$. bydrophila infections have been described. However, A. bydrophila is also known to secrete a number of degradative enzymes, such as proteases (Leung \& Stevenson, 1988), DNase (Chang et al., 1992b), RNase (Favre et al., 1993) and lipases (Anguita et al., 1993). It has been suggested that lipases may provide bacterial nutrients (Hedstrom $\&$ Nisson, 1975) and constitute virulence factors by interacting with human leukocytes (Rollof et al., 1988) or by affecting several immune system functions through 
free fatty acids generated by lipolytic activity (Buttke $\&$ Cuchens, 1984; Eftimiadi et al., 1987). In addition, a number of potential industrial applications for microbial lipases have been developed (Harwood, 1989). Consequently, the use of these enzymes in industry is expected to increase.

In the present work, we have undertaken the biochemical characterization and the genetic study of an extracellular lipase from $A$. bydrophila. The properties of this lipase are compared with those of the other lipases previously characterized from different strains of A. hydrophila.

\section{METHODS}

Bacterial strains, plasmids and cultivation condition. A. bydrophila MCC-2 was used in this study. It was initially isolated from a blood culture of a hospitalized patient and identified by the Culture Collection and Research Center, Food Industry Research and Development Institute, Hsinchu, Taiwan, Republic of China. Escherichia coli JA221 (Beggs, 1978) and E. coli JM109 (Yanisch-Perron et al., 1985) were used as hosts for recombinant plasmids. E. coli $\mathrm{P} 678-54\left(\mathrm{~F}^{-}\right.$ thr leu thi supE lacY fbuA gal mal $x y l$ mtl) was used as minicell-producing strain. For labelling of proteins with $\left[{ }^{3} \mathrm{H}\right]$ palmitate, E. coli M15 ( $\mathrm{F}^{-} \mathrm{Nal}^{\mathrm{s}} \mathrm{Str}^{\mathrm{s}} \mathrm{R}$ if $\mathrm{f}^{\mathrm{s}}$ lac ara gal mtl) (QIAGEN) was employed. Plasmid pBR322 (Bolivar et al., 1977) was used in cloning experiments; plasmids pUC18 and pUC19 (Vieira \& Messing, 1982) were used in subcloning experiments.

A. hydrophila and E. coli were usually grown in LB medium (Sambrook et al., 1989) at $30^{\circ} \mathrm{C}$ and $37^{\circ} \mathrm{C}$, respectively. For screening lipolytic clones, tributyrin plates containing $0.4 \%$ caso agar (Merck), $0.1 \%$ gum arabic, $1.0 \%(\mathrm{v} / \mathrm{v})$ tributyrin, $50 \mu \mathrm{g}$ ampicillin $\mathrm{ml}^{-1}$ and $1.5 \%$ agar were used. When necessary, the medium was supplemented with IPTG to a final concentration of $1 \mathrm{mM}$.

Construction and screening of the DNA library. All DNA manipulations were carried out in accordance with the manufacturers' instructions and as described by Sambrook et al. (1989). The preparation of the DNA library containing $A$. bydrophila genomic DNA in the vector pBR322 has been described previously (Chang et al., 1993). The A. bydrophila MCC-2 genomic DNA library was constructed in a similar manner. The gene bank was used to transform E. coli JA221 and transformants were selected on tributyrin plates. After $48 \mathrm{~h}$ incubation at $37^{\circ} \mathrm{C}$, the colonies that had clear zones around them were isolated.

Enzyme activity measurements. Esterase activity was assayed spectrophotometrically using $p$-nitrophenyl butyrate as substrate. The reaction was carried out at $37^{\circ} \mathrm{C}$ in $20 \mathrm{mM}$ phosphate buffer $(\mathrm{pH} 7 \cdot 4)$ containing $0.2 \%$ Triton X-100, $5 \mathrm{mM}$ p-nitrophenyl butyrate, and enzyme. The reaction was stopped with methanol and the absorbance at $420 \mathrm{~nm}$ recorded. One unit of esterase activity is defined as the activity which liberates $1 \mu \mathrm{mol} p$-nitrophenol $\mathrm{min}^{-1}$ under the assay conditions used. Substrate specificity was measured using $p$ nitrophenyl esters of different chain lengths (purchased from Sigma), which were emulsified completely by sonication in the presence of $0.5 \%$ Triton X-100.

Lipase activity was measured by the titrimetric method as described by Anguita et al. (1993), with tributyrin emulsions used as substrate. One unit of lipase activity is defined as the activity which liberates $1 \mu \mathrm{mol}$ free fatty acids $\mathrm{min}^{-1}$ under the assay conditions used. Phospholipase activity was tested by the method described by Ingham \& Pemberton (1995). Substrate specificity was measured using various triacylglycerol emulsions (purchased from Sigma). During purification, the spectrophotometric method was used for tracing of lipase activity, with $p$-nitrophenyl butyrate as substrate. $\beta$ Galactosidase and $\beta$-lactamase activities were assayed as described previously (Chang et al., 1992b). Protein concentrations were determined using a protein assay kit (Bio-Rad) with bovine serum albumin as standard.

Minicell isolation and labelling of proteins. Minicells were isolated from E. coli P678-54 containing the appropriate plasmid, and proteins were labelled with $\left[{ }^{35} \mathrm{~S}\right]$ methionine by methods described previously (Doagan \& Kehoe, 1984; Chang et al., 1992a). The labelled plasmid-encoded proteins were separated by SDS-PAGE (Laemmli, 1970) and identified by direct autoradiography of the dried gel, using X-ray film.

Minicell fractionation and cellular fractionation. Labelled minicells were collected and converted to spheroplasts by the method of van Doorn et al. (1982). The periplasmic proteins will remain in the supernatant when the spheroplasts are pelleted. The spheroplasts were lysed by five cycles of freezing-thawing. After removal of unlysed spheroplasts and minicells, the total membrane (pellet) and cytoplasmic fractions (supernatant) were collected by centrifugation $(15000 \mathrm{~g}$, $30 \mathrm{~min})$. The proteins present in the various fractions of minicells were separated by SDS-PAGE (Laemmli, 1970). Extracellular, periplasmic and cytoplasmic cell fractions of E. coli JM109 were prepared as described previously (Chang et al., 1993). The total membrane of E. coli was further separated into cytoplasmic and outer membrane fractions with a discontinuous sucrose gradient (Gennity et al., 1992) for unlabelled cells or with sodium lauryl sarcosinate (Filip et al., 1973) for $\left[{ }^{35} \mathrm{~S}\right]$ methionine-labelled cultures.

DNA sequencing and sequence analysis. All sequences were determined on denatured dsDNA templates by the dideoxy chain-termination method (Sanger et al., 1977), using a Sequenase 2.0 DNA sequencing kit (USB) and $\left[{ }^{35} \mathrm{~S}\right] \mathrm{dATP} \alpha \mathrm{S}$ sequencing grade $\left(>12.5 \mathrm{mCi} \mathrm{ml}^{-1},>463 \mathrm{MBq} \mathrm{ml}^{-1}\right.$; sp. act. 1000-1500 Ci mmol ${ }^{-1}, 37-55.5 \mathrm{TBq} \mathrm{mmol}^{-1}$ ) (New England Nuclear). Universal and reverse primers were used to obtain the initial sequences within the inserts, and then specific primers for the sequences within the inserts were generated. Conditions for DNA sequencing were as described in the Sequenase brochure (USB). Denaturing $6 \%$ polyacrylamide $\mathrm{PAGE}$ at $60 \mathrm{~W}$ was used to separate the reaction products. The gels were exposed to X-ray film (Kodak Omat-AR) overnight. DNA was sequenced in both directions. In some cases, dITP was used in place of dGTP for a more reliable reading through regions of high $\mathrm{G}+\mathrm{C}$ content. Sequence analysis was carried out with a PC/GENE software package (Intelligenetics).

Construction of lip expression plasmid pQEL1. Two DNA oligonucleotide primers were designed to allow the PCR amplification of the entire lip gene from plasmid pLP12. The forward primer (5'-AGCATGCGAAGAAAAAGCTAATTTACGC-3') and the reverse primer (5'-TGCTTAGCAGGTACCCGTCGGTCA-3') were synthesized (see Fig. 3). The forward primer contained a SphI restriction site and showed sequence identity with nucleotides 547 to 574 of the lip gene, and the reverse primer contained a $K p n I$ site and contained a sequence complementary to nucleotides 2805 to 2828 of the lip gene. PCR amplification was performed with $50 \mathrm{pmol}$ of each primer, $200 \mu \mathrm{M}$ of each deoxynucleoside triphosphate and $2 \mathrm{ng}$ of plasmid pLP1 DNA as template in a total volume of $50 \mu$ l. Taq polymerase was obtained from Amersham and was used under buffer conditions recommended by the manu- 
facturer. PCR was carried out for 30 cycles as described by Innis \& Gelfand (1990). The PCR product was purified by phenol/chloroform extraction followed by ethanol precipitation and a wash with $70 \%$ ethanol; it was then dried and resuspended in $30 \mu \mathrm{l}$ distilled water. The DNA was then cleaved with $S p h \mathrm{I}$ and $K p n \mathrm{I}$ and run on a $0.7 \%$ agarose gel in TBE buffer (Sambrook et al., 1989). DNA bands stained with ethidium bromide were visualized under long-wave length UV light and cut from the gel. The vectors, pQE-50, -51, -52 (QIAexpress kits purchased from QIAGEN), were prepared by cleaving $2 \mu \mathrm{g}$ vector DNAs with $S p h \mathrm{I} / K p n \mathrm{I}$ and cutting the linearized DNAs band from the gel. About $200 \mathrm{ng}$ insert DNA was ligated to $100 \mathrm{ng}$ vector DNAs and the ligated plasmids were used to transform competent cells of E. coli M15(pREP4) (supplied in the QIAexpress kits), which were then plated on LB plates containing $100 \mu \mathrm{g}$ ampicillin $\mathrm{ml}^{-1}$ and $25 \mu \mathrm{g}$ kanamycin $\mathrm{ml}^{-1}$. After overnight incubation at $37^{\circ} \mathrm{C}$, colonies were selected on tributyrin plates to screen for the correct insertion of the coding fragment. The resulting plasmid, pQEL1, was rescued as described by Sambrook et al. (1989).

Labelling of proteins with $\left[^{3} \mathrm{H}\right]$ palmitate. E. coli M15 containing pQEL 1 and pREP4 was grown in LB broth supplemented with $100 \mu \mathrm{g}$ ampicillin $\mathrm{ml}^{-1}$ and $25 \mu \mathrm{g}$ kanamycin $\mathrm{ml}^{-1}$. The cells were grown to exponential phase and $\left[{ }^{3} \mathrm{H}\right]$ palmitate $\left(5 \mathrm{mCi} \mathrm{ml}^{-1} ; 185 \mathrm{MBq} \mathrm{ml}^{-1}\right)$ (DuPont-NEN) and IPTG were added to a final concentration of $25 \mu \mathrm{Ci} \mathrm{m}^{-1}$ and $5 \mathrm{mM}$, respectively, and incubation was continued for $5 \mathrm{~h}$. The cells were collected by centrifugation and washed three times with methanol to remove noncovalently bound lipids. The dried pellets were resuspended in sample buffer and analysed by SDS-PAGE (Laemmli, 1970). The radiolabelled proteins were detected by autoradiography by using Amplify (Amersham) to enhance the signals and X-ray film.

Purification of lipase and activity-staining. A. hydrophila or E. coli JM109 harbouring PQEL1 were grown to stationary phase in $21 \mathrm{LB}$ medium containing $50 \mu \mathrm{g}$ ampicillin $\mathrm{ml}^{-1}$, and the extracellular and the membrane fractions were prepared as described above. Lipases from the culture supernatant of $A$. bydrophila and from the E. coli cell membrane preparation were purified as described below. All procedures were carried out at $4{ }^{\circ} \mathrm{C}$ unless otherwise indicated. The starting material was fractionated with finely powdered ammonium sulfate, and the $25-50 \%$ of ammonium-sulfate-precipitated material was resuspended in $50 \mathrm{mM}$ phosphate buffer ( $\mathrm{pH} 7.5$ ) before being applied to a PD-10 column (Pharmacia) to remove salts. The desalting materials were applied to a DEAE-Sepharose CL-6B column $(2.6 \times 15 \mathrm{~cm})$ pre-equilibrated with $50 \mathrm{mM}$ phosphate buffer $(\mathrm{pH} 7 \cdot 5)$. The enzyme was eluted with $500 \mathrm{ml}$ of a linear gradient of $0-1.0 \mathrm{M} \mathrm{NaCl}$ in the same buffer. The eluted enzyme fraction was concentrated on a membrane (YM3; Amicon) and then subjected to gel filtration on a Sephadex G-100 column $(2.2 \times 100 \mathrm{~cm})$ pre-equilibrated with $50 \mathrm{mM}$ phosphate buffer $(\mathrm{pH} 7 \cdot 5)$. Fractions were eluted at a flow rate of $20 \mathrm{ml} \mathrm{h}^{-1}$ in the same buffer, and the highest lipolytic fractions were pooled and applied to a CM-Sepharose column $(1 \times 10 \mathrm{~cm})$ pre-equilibrated with $50 \mathrm{mM}$ phosphate buffer $(\mathrm{pH} 7 \cdot 5)$. The lipase was eluted with $50 \mathrm{ml}$ of a linear gradient of $0-0.5 \mathrm{M} \mathrm{NaCl}$ in the same buffer, and the active fractions were collected. Purification was monitored by SDSPAGE (Laemmli, 1970). Lipase-activity staining was performed as described by Lee et al. (1993) with the modification that Tween 80 was used instead of tributyrin as substrate. After electrophoresis, the polyacrylamide gel was laid on $2.0 \%$ agarose gel containing $40 \mathrm{mM}$ Tris/ $\mathrm{HCl}$ (pH 7.8), $50 \mathrm{mM} \mathrm{CaCl}$ and $2.0 \%$ Tween 80 . The attached gel was incubated for $8 \mathrm{~h}$ at $37^{\circ} \mathrm{C}$.

\section{RESULTS}

\section{Cloning of the lip gene of $A$. hydrophila}

To clone the gene encoding the extracellular lipase of $A$. hydrophila MCC-2, a genomic library of this organism was constructed in E. coli JA221. Transformed E. coli cells were screened on tributyrin-containing medium to select tributyrin-degrading clones. Among approximately 5000 transformants, two colonies forming a clear zone were detected. Plasmid DNA was isolated from these two independent clones and subjected to restriction endonuclease mapping. The inserts of the two plasmids (pLP1 and pLP2) were identical, except that the pLP1 insert $(7.5 \mathrm{~kb})$ was $2 \mathrm{~kb}$ smaller than that of pLP2. To determine the approximate location of the lip gene in the cloned DNA fragment, several subclones were generated from pLP1: for each subclone, the ability to grow on tributyrin-containing medium was assayed, and the presence of lipase activity determined. The results of subcloning revealed that a $2.9 \mathrm{~kb}$ HindIII-XhoI fragment was sufficient for the lipase production in E. coli JM109 (pLP12) or JM109 (pLP21) (Fig. 1). Since lipase is expressed both from pLP12 and from $\mathrm{pLP} 21$, an active promoter on the cloned fragment must transcribe lip. In addition, the clear zones formed around colonies containing pLP21 were smaller than those formed around colonies containing pLP12, indicating that the lac Z promoter on $\mathrm{pLP} 12$ contributes to transcription of lip.

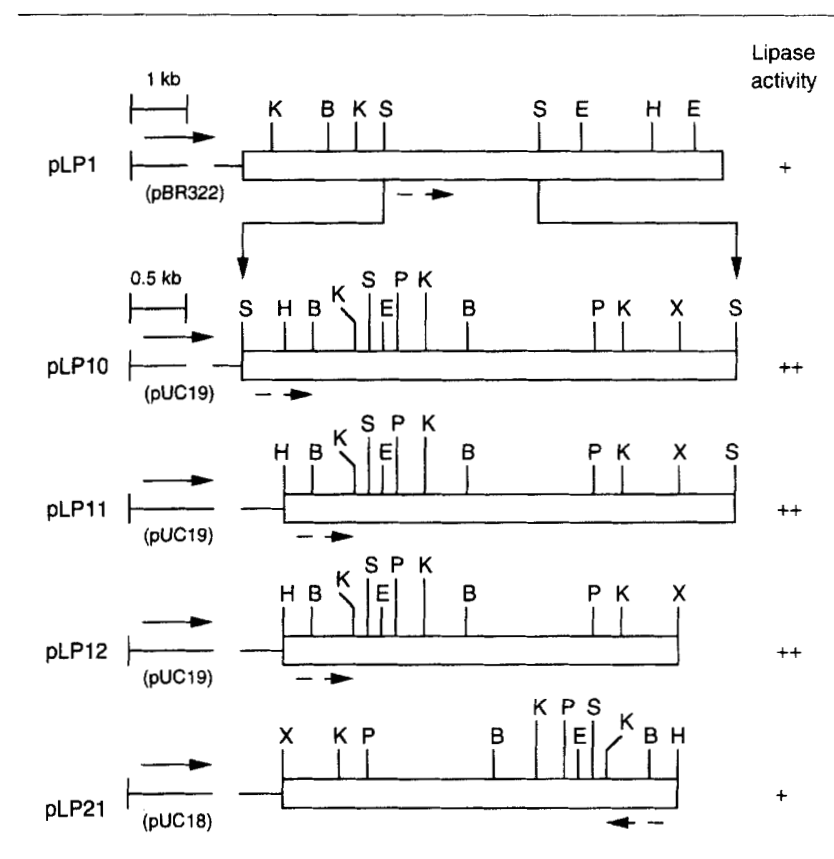

Fig. 1. Restriction endonuclease maps of plasmid clones harbouring the lipase gene. B, BamHI; E, EcoRI; H, HindllI; K, Kpnl; P, Pstl; S, Sphl; X, Xhol. Boxes indicate A. hydrophila DNA; thin lines indicate DNA from the plasmid vectors $p B R 322$, pUC18 or pUC19; solid arrows indicate the direction of transcription of the tetracycline promoter (pLP1) or the lacZp promoter ( $\mathrm{pLP} 10, \mathrm{pLP} 11, \mathrm{pLP} 12$ and $\mathrm{pLP} 21$ ); dashed arrows indicate the direction of the putative promoter of the cloned gene. Varying levels of activity are represented by + and ++ . 


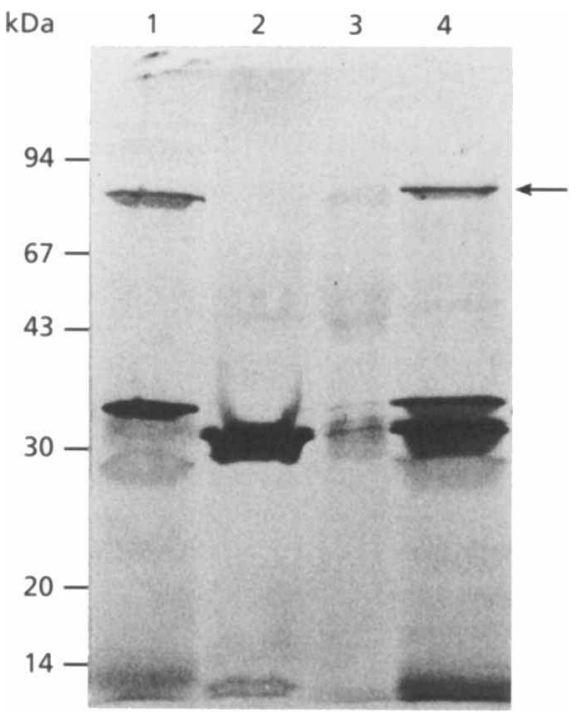

Fig. 2. ${ }^{35} \mathrm{~S}$-labelled polypeptides from the various fractions of pLP12-containing minicells. Extracts were applied to the gel from whole cells (lane 4), the cytoplasm (lane 3), the periplasmic fluid (lane 2) and total membrane (lane 1). The lip gene product is shown by an arrow.

\section{Detection and cellular distribution of lipase in E. coli transformants}

To identify the product encoded by the cloned lip in $E$. coli, pLP12 was transformed into the minicell strain P678-54. Polypeptides encoded by pLP12 and the vector pUC19 were detected by labelling with $\left[{ }^{35} \mathrm{~S}\right]$ methionine. A unique $80 \mathrm{kDa}$ polypeptide was expressed in the strain carrying pLP12 (Fig. 2, lane 4), and the inability to produce the $80 \mathrm{kDa}$ polypeptide was observed in the strain containing pUC19 (data not shown).

Measurement of extracellular lipase activity produced by $A$. hydrophila MCC-2 indicated that activity was very low in exponentially growing cells and the activity increased rapidly in cells of the early stationary phase. Lipase activity was detected neither in the cytoplasm nor in the periplasmic fluids of cells during the exponential growth phase or during the stationary phase (data not shown). To localize the lip gene product within $E$. coli P678-54 harbouring pLP12, the labelled minicells were fractionated into periplasmic, cytoplasmic and membrane fractions. SDS-PAGE analysis revealed that the $80 \mathrm{kDa}$ Lip protein was detected exclusively in the membrane fraction of E. coli minicells (Fig. 2, lane 1). Enzyme assays revealed that the majority of the lipase activity was also located in the E. coli P678-54 membrane fraction (about $70 \%$ ). When the membrane fraction of E. coli P678-54 was further separated into inner and outer membrane fractions utilizing the detergent lauryl sarcosinate, SDS-PAGE analysis showed that the $80 \mathrm{kDa}$ protein was in both fractions (data not shown). To investigate whether this was the case with the cloned Lip in E. coli JM109, cells harbouring pLP12 were harvested in early stationary phase and fractionated, and the activity of lipase in these different cell
Table 1. Distribution of lipase and marker enzymes in early stationary phase growth of E. coli JM109(pLp12)

Enzyme activities are given as the percentage of the total activity. Experiments were performed in triplicate, and the ranges of values are given.

\begin{tabular}{|lccc|}
\hline Fraction & \multicolumn{3}{c|}{ Enzyme activity } \\
\cline { 2 - 4 } & Lipase & $\boldsymbol{\beta}$-Lactamase & $\boldsymbol{\beta}$-Galactosidase \\
\hline Supernatant & $5-12$ & $10-15$ & $0-6$ \\
Periplasm & $5-12$ & $65-80$ & $0-5$ \\
Cytoplasm & $4-8$ & $4-8$ & $75-85$ \\
Membrane & $70-85$ & $5-10$ & $10-18$ \\
\hline
\end{tabular}

compartments was determined. As controls, $\beta$-lactamase (a periplasmic marker enzyme) and $\beta$-galactosidase were also assayed for each fraction. The results revealed that $\beta$-lactamase was found predominantly in the periplasmic fraction, and $\beta$-galactosidase in the cytoplasmic fractions. Most of the lipase activity, however, was detected in the membrane fraction (Table 1).

\section{Nucleotide sequence of lip gene}

The nucleotide sequence of the $2.9 \mathrm{~kb}$ DNA fragment encompassing the lip gene was determined on both strands. Computer analysis of the nucleotide sequence identified the ORF for lip (Fig. 3), extending from an ATG codon at nucleotide 552 to a TGA stop codon at position 2804 , which is sufficient to encode a protein of 751 amino acids corresponding to a molecular mass of $79921 \mathrm{Da}$. A putative ribosome-binding site (ShineDalgarno sequence) was tentatively placed between nucleotide positions 539 and 544 at 7 bp upstream from the ATG. We have not attempted to locate a promoter region upstream of the putative translational start site. A potential transcription termination structure was identified at positions 2845 to 2872 . The $\mathrm{G}+\mathrm{C}$ content of the A. bydrophila lip gene $(65 \mathrm{~mol} \%)$ is nearly identical to those for glycerophospholipid-cholesterol acyltransferase (GCAT) $(62 \mathrm{~mol} \%$; Thornton et al., 1988 ), $\alpha$-amylase (63 mol \% ; Chang et al., 1993), a mylase (62 mol\%; Gobius \& Pemberton, 1988), deoxyribonuclease (DNase) (63 mol\% ; Chang et al., 1992b), nuclease (64 mol\%; Dodd \& Pemberton, 1996) and lipase (63 mol\% ; Anguita et al., 1993), and is a little higher than that for aerolysin $(58 \mathrm{~mol} \%$; Howard et al., $1987)$ from this species. The codon usage frequency in the lip gene is similar to the pattern for the aforementioned genes of this species (data not shown).

\section{Analysis of the Lip amino acid sequence}

Application of a program (von Heijne, 1986) for identification of prokaryotic secretory signal sequences predicted that Lip contains a signal peptidase cleavage site between residues 48 and 49 (Ala-Ala). However, we also found a second possible cleavage site between 


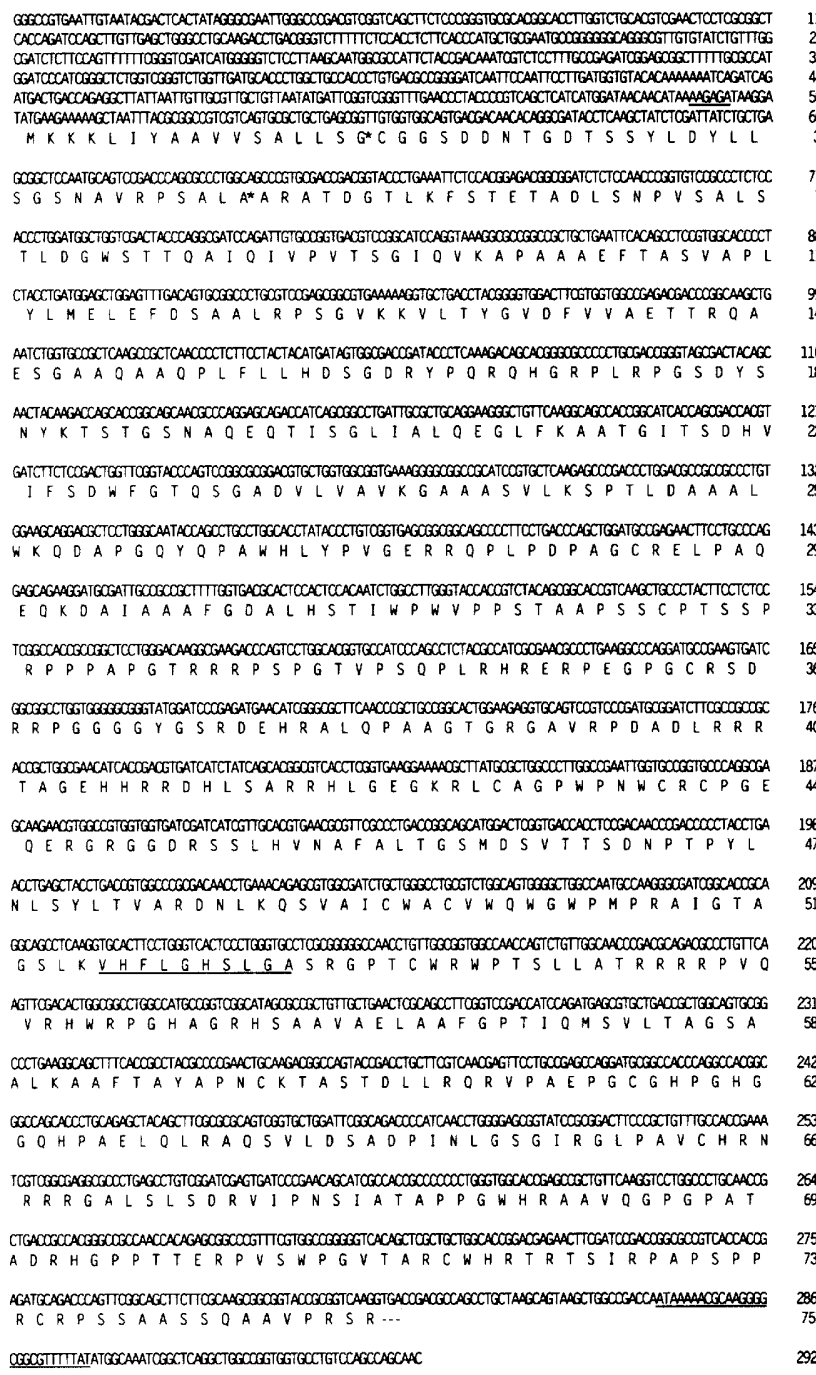

Fig. 3. Nucleotide and deduced amino acid sequences of the lip gene of $A$. hydrophila. Numbers refer to the nucleotide or amino acid located at the end of each line. The putative Shine-Dalgarno sequence is underlined. The lipase consensus sequence at positions 518 to 527 is shown. The putative palindromic transcription termination structure (positions 2845 to 2872 ) is also underlined. The asterisks after the 17th and 48th amino acids indicate the two potential leader peptide cleavage sites.

residues 17 and 18 (Gly-Cys). This second site has a strong resemblance to known lipoprotein signal peptide sequences when aligned with the cysteine residue as +1 (Wu \& Tokunaga, 1986). The unprocessed protein appears to be highly basic, with an estimated pI of $10 \cdot 36$, and contains nine Cys residues, some of which may form disulfide bonds important in the secondary structure of the protein. Additionally, the enzyme contains the sequence Val-His-Phe-Leu-Gly-His-Ser-Leu-Gly-Ala (positions 518 to 527), which matches almost perfectly the consensus sequence of lipases of different origins and with different biochemical properties. It is generally supposed that this consensus sequence represents the substrate-binding domain of lipase enzymes (Antonian, 1988 ) and that the central serine of the conserved

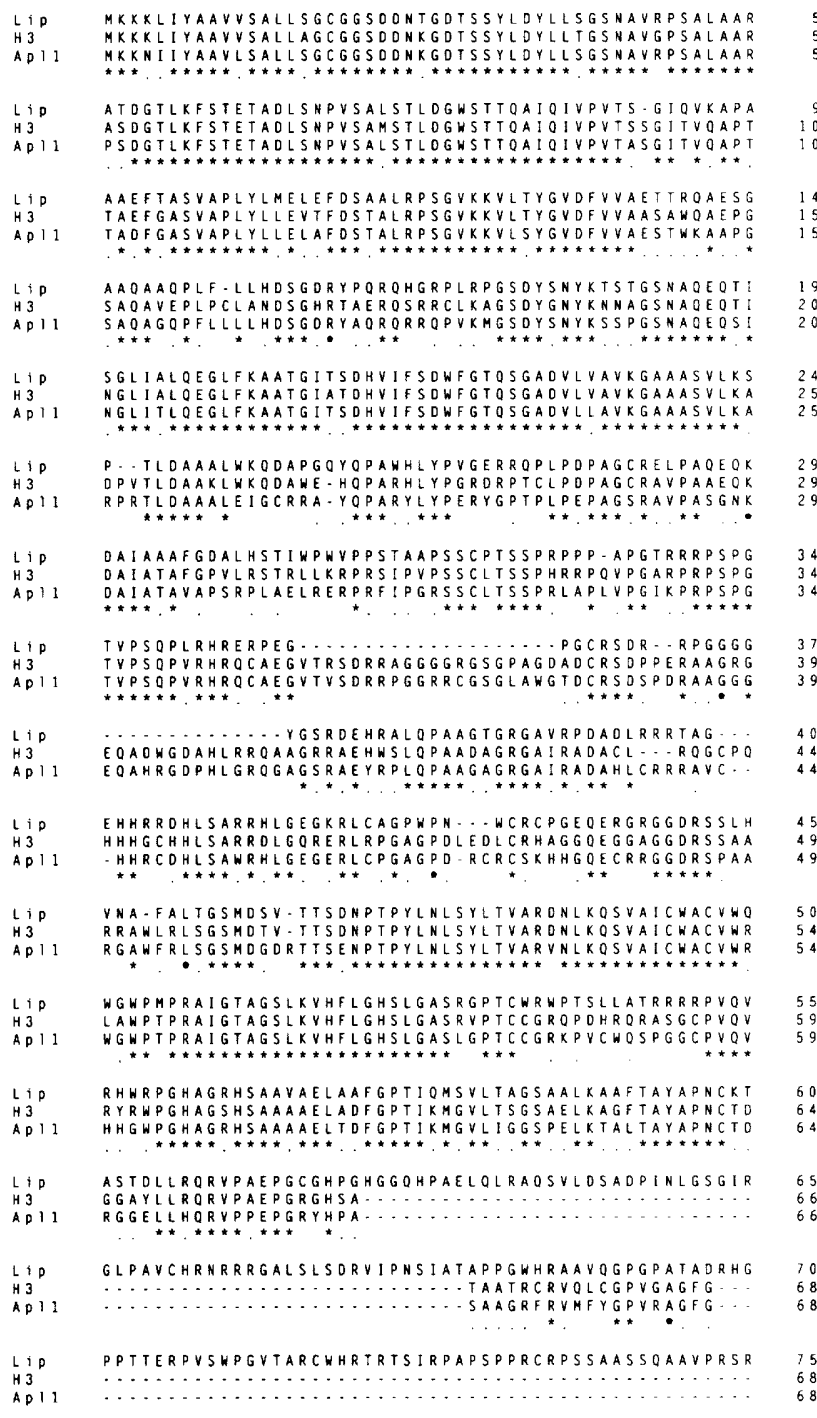

50
50
50

109

149
150
150

150

198
200

248
250

250

296

299

345
349
349

373
399

399

406
446

447

453
496

495

5011
545
545

Fig. 4. Comparison of the deduced amino acid sequences of $A$. hydrophila Lip protein (Lip), H3 lipase (H3) and Apl-1 lipase (Apl1). The amino acid sequence numbers are listed on the right. Asterisks indicate identical residues and dots show conservative substitutions. Gaps introduced for alignment are represented by dashes.

pentapeptide Gly-Xaa-Ser-Xaa-Gly within this sequence is the nucleophilic residue essential for catalysis (Faustinella et al., 1991).

The predicted amino acid sequence of Lip protein was compared with those of other well characterized lipases from $A$. bydrophila strains. Significant divergence was observed between the predicted amino acid sequence of Lip protein and the lipase/acyltransferase, which has been cloned from strain Ah65 (Hilton et al., 1990; data not shown). However, the Lip protein showed strong similarity to the $\mathrm{H} 3$ lipase and Apl-1 lipase, which have been cloned from strains $\mathrm{H} 3$ and JMP636, respectively (Anguita et al., 1993; Ingham \& Pemberton, 1995). Over the entire sequence, the Lip protein was $67 \%$ identical to the $\mathrm{H} 3$ lipase and $65 \%$ identical to the Apl-1 lipase. Sequence alignment analysis (Fig. 4) showed that a 


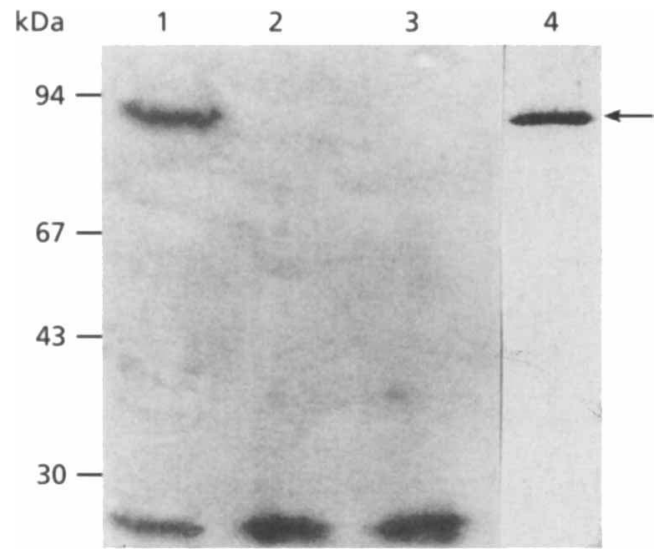

Fig. 5. $\left[{ }^{3} \mathrm{H}\right]$ Palmitate labelling of lipoproteins from $E$. coli and SDS-PAGE of purified lipase. Lanes 1-3, autoradiograph of SDSPAGE preparations from cells (carrying pREP4 and pQEL1) labelled with $\left[{ }^{3} \mathrm{H}\right]$ palmitate in the presence of IPTG inducer (lane 1), in the absence of IPTG inducer (lane 2) and cells (carrying PREP4) labelled in the presence of IPTG inducer (lane 3). Lane 4, lipase purified from $A$. hydrophila MCC-2 stained with Coomassie blue G250. The arrow indicates the position of Lip protein purified from $E$. coli carrying PQEL1, determined by Coomassie staining of the gel.

major difference between Lip and these two proteins exists, namely that Lip lacks 37 amino acid residues corresponding to Gly-380 to Arg-416 in H3 lipase and Gly-380 to Ser-416 in Apl-1 lipase. In addition, Lip contains an additional 100 amino acids at the C-terminal end which are not present in either $\mathrm{H} 3$ lipase or Apl-1 lipase. No other significant similarities were observed with other nucleotide or protein sequences available in the EMBL-GenBank or SWISS-PROT databases.

\section{Post-translational modification of Lip}

The presence of a consensus processing site for lipoprotein suggested the possibility that the cloned lip gene product was subject to post-translational lipid modifi- cation when expressed in E. coli. To test this possibility, a lip expression plasmid, pQEL1, was constructed. E. coli M15 harbouring plasmid pREP4 was transformed with $\mathrm{PQEL} 1$, and palmitate labelling was carried out (Fig. 5). In addition to labelling of the native E. coli lipoproteins, there was substantial labelling of cloned Lip in E. coli M15 cells harbouring pQEL1 and pREP4 grown in the presence of $\left[{ }^{3} \mathrm{H}\right]$ palmitate and IPTG inducer (Fig. 5, lane 1). No significant labelling of cloned Lip in uninduced $E$. coli M15 harbouring pQEL1 and pREP4 cells, or in E. coli harbouring pREP4 cells was seen (lanes 2 and 3).

\section{Purification and characterization of lipase}

Cultures of A. hydrophila or E. coli transformed with pQEL1 were fractionated and the culture supernatants were used as crude preparations for enzyme purification. A typical procedure for purification of the lipase from culture supernatant of $A$. bydrophila MCC-2 is summarized in Table 2. The same protocol was also performed for purification of Lip protein from the membrane fraction of $E$. coli transformed with pQEL1. After examination of both purified lipase preparations by SDS-PAGE, a single band with a molecular mass of $80 \mathrm{kDa}$ was observed (Fig. 5, lane 4), which corresponded to the active lipase bands obtained on a renaturing polyacrylamide gel (Fig. 6). A single active lipase band was present in the crude enzyme preparations from culture supernatant of A. hydrophila (Fig. 6, lane 1), indicating that $A$. bydrophila may produce only one extracellular lipase, whose matured form has a molecular mass of $80 \mathrm{kDa}$.

The optimal activity of the Lip protein was at a $\mathrm{pH}$ range of 7.5 to 8.0 when $p$-nitrophenyl butyrate was used as substrate. No activity was detected below pH $5 \cdot 0$ or above $\mathrm{pH}$ 9.5. In the optimal $\mathrm{pH}$ range, maximal enzyme activity was obtained at $37^{\circ} \mathrm{C}$ and the enzyme was stable below $50{ }^{\circ} \mathrm{C}$; after being incubated for $30 \mathrm{~min}$ at $55^{\circ} \mathrm{C}$, only $20 \%$ of the activity remained. To investigate the substrate specificity of Lip protein, we tested esterase and lipase activities by using $p$-nitrophenyl derivatives

Table 2. Summary of the purification of extracellular lipase from A. hydrophila MCC-2.

\begin{tabular}{|c|c|c|c|c|c|}
\hline Purification step & $\begin{array}{c}\text { Total } \\
\text { protein } \\
(\mathbf{m g})\end{array}$ & $\begin{array}{c}\text { Total } \\
\text { activity } \\
\text { (U) }\end{array}$ & $\begin{array}{c}\text { Specific } \\
\text { activity } \\
\left(\mathrm{U} \mathrm{mg}^{-1}\right)^{*}\end{array}$ & Yield & $\begin{array}{l}\text { Purification } \\
\text { factor }\end{array}$ \\
\hline Supernatant & 180 & 2880 & $1 \cdot 6$ & 100 & 1 \\
\hline $\begin{array}{l}25-50 \% \text { ammonium } \\
\text { sulfate }\end{array}$ & 47 & 1645 & $3 \cdot 6$ & 57 & $2 \cdot 3$ \\
\hline $\begin{array}{l}\text { DEAE-Sepharose } \\
\text { CL-613 }\end{array}$ & 6 & 81 & $13 \cdot 5$ & 28 & $8 \cdot 5$ \\
\hline Sephadex G-100 & 0.9 & 48 & $53 \cdot 5$ & 17 & 33 \\
\hline
\end{tabular}

*One unit is the amount of enzyme which releases $1 \mu \mathrm{mol} p$-nitrophenol $\min ^{-1}$ at $37^{\circ} \mathrm{C}$ under the assay conditions used. 


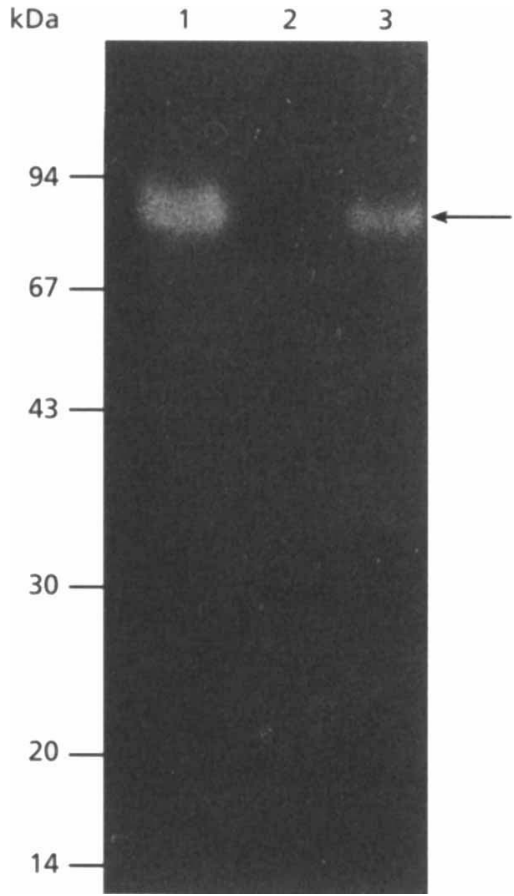

Fig. 6. Analysis of lipase activity in crude cell extracts by SDSPAGE followed by gel renaturation. Lanes: 1, culture supernatants of $A$. hydrophila MCC-2; 2, extracts from $E$. coli (pUC19); 3 , extracts from E. coli(pLP12). The position of the lipase activity, detected in lanes 1 and 3, is shown by an arrow.

Table 3. Esterase activity of Lip protein against several $p$-nitrophenyl esters and triacylglycerols

\begin{tabular}{|c|c|c|c|c|}
\hline \multirow{3}{*}{$\begin{array}{l}\text { Acyl group } \\
\text { substrate }\end{array}$} & \multicolumn{4}{|c|}{ Esterase activity of Lip protein against: } \\
\hline & \multicolumn{2}{|c|}{$p$-Nitrophenyl derivatives } & \multicolumn{2}{|c|}{ Triacylglycerols } \\
\hline & $\mathrm{U} \mathrm{mg}^{-1 *}$ & $\% \dagger$ & $\mathrm{U} \mathrm{mg}^{-1 *}$ & $\% \dagger$ \\
\hline Acetate & 0 & 0 & 0 & 0 \\
\hline Butyrate & $13 \cdot 9$ & $12 \cdot 1$ & $13 \cdot 5$ & $15 \cdot 3$ \\
\hline Caproate & $78 \cdot 8$ & $68 \cdot 5$ & $44 \cdot 1$ & $50 \cdot 1$ \\
\hline Caprylate & $86 \cdot 3$ & $75 \cdot 0$ & $79 \cdot 2$ & $90 \cdot 0$ \\
\hline Caprate & $115 \cdot 1$ & 100 & $88 \cdot 0$ & 100 \\
\hline Laurate & $106 \cdot 0$ & $92 \cdot 1$ & $61 \cdot 6$ & $70 \cdot 0$ \\
\hline Myristate & $43 \cdot 7$ & $38 \cdot 0$ & $22 \cdot 0$ & $25 \cdot 0$ \\
\hline Palmitate & 0 & 0 & 0 & 0 \\
\hline
\end{tabular}

"Data are means from triplicate determinations.

†Percentage of the maximum activity detected.

and triacylglycerols, respectively. The results (Table 3) show that esterase activity was detected against substrates with chain lengths from $\mathrm{C}_{4}$ to $\mathrm{C}_{14}$ and the highest esterase activity was observed with the substrate $p$ nitrophenyl caprate $\left(\mathrm{C}_{10}\right)$. The highest lipase activity was observed with tricaprylin $\left(\mathrm{C}_{8}\right)$ and tricaprin $\left(\mathrm{C}_{10}\right)$ as substrates. Only $25 \%$ of the maximum lipase activity was detected with $\mathrm{C}_{14}$ and no lipolytic activity was observed with $\mathrm{C}_{16}$. To further characterize the Lip protein specificity, we analysed phospholipase activity by using various phospholipids as substrates. No phospholipase activity was detected.

\section{DISCUSSION}

The present paper describes the gene encoding the extracellular lipase of $A$. bydrophila MCC-2 and shows that the lip gene product is readily expressed in $E$. coli under the control of its own promoter. The Lip protein is encoded by an ORF of $2253 \mathrm{bp}$. This ORF codes for a protein of 751 amino acids corresponding to a $79.9 \mathrm{kDa}$ polypeptide. The start codon was identified by its location $7 \mathrm{bp}$ downstream from the sequence $5^{\prime}$ AAGAGA-3', which is typical of sequences known to function as ribosome-binding sites in E. coli (Shine \& Dalgarno, 1974). The translational stop codon TGA, 2253 bp downstream, defines the C-terminal end of the protein and is the preferred stop codon for A. hydrophila (Howard et al., 1987; Thornton et al., 1988; Chang et al., 1993; Favre et al., 1993), in contrast to the overall tendency in prokaryotes to be biased towards TAA (Kohli \& Grosjean, 1981; Ikemura \& Ozeki, 1982).

Although a putative signal sequence was identified, and the predicted cleavage site between Ala and Ala (at positions 48 and 49 ) is typical of leader sequences of secreted proteins which are cleaved by signal peptidase I (von Heijne, 1986), it was also noted that this cleavage site was preceded by the sequence Leu-Leu-Ser-Gly-Cys, which bears a strong resemblance to the consensus SPase II recognition site of known lipoproteins (Wu \& Tokunaga, 1986). Attempts to determine the $\mathrm{N}$-terminal amino acid sequence of the purified recombinant Lip protein were unsuccessful. In contrast, the lipoprotein nature of Lip was seen when E. coli M15 cells containing pQEL1 grown in the presence of $\left[{ }^{3} \mathrm{H}\right]$ palmitate and IPTG inducer were shown to produce ${ }^{3} \mathrm{H}$-labelled Lip which was not detected in the absence of inducer. Using a bacterial lipoprotein, bacteriocin release protein (BRP), fused to $\beta$-lactamase, it was shown that the signal peptide plus the Cys of BRP was sufficient for the lipid modification and processing (Oudega et al., 1993). Similarly, an in vitro study using the signal peptide plus four N-terminal amino acids of mature Braun's lipoprotein supported this conclusion (Sankaran \& Wu, 1994). Additionally, lipoproteins or lipoprotein intermediates, such as the pullulanase of Klebsiella pneumoniae (d'Enfert et al., 1987), pectinesterase of Pseudomonas solanacearum (Spok et al., 1991), EGL endoglucanase of $P$. solanacearum (Huang \& Schell, 1992) and cel3 endoglucanase of Fibrobacter succinogenes (McGavin et al., 1989) contain this consensus cleavage sequence near their $\mathrm{N}$ termini and, when produced in $E$. coli, showed evidence of lipid modification and membrane association. Likewise, our results indicated that the Lip protein was primarily membrane-associated and lipid-modified in E. coli. Examination of the hydropathy 
profile of this protein and analysis of the amino acid sequence, using the software program PC/GENE, revealed that it is predominantly hydrophilic rather than amphiphilic and contains only one potential transmembrane segment, corresponding to the region of the predicted signal peptide. Therefore, we propose that the lipoprotein consensus sequence in the Lip protein serves as a signal for lipid modification, and the result of the lipid modification is directly responsible for stable association of the protein with the inner face of the outer membrane and the outer face of the inner membrane. This proposal will be tested by site directed mutagenesis of the lipidmodification site.

Since the Lip protein was found to show only limited homology to A. hydrophila Ah65 lipase/acyltransferase, which shares several properties with mammalian plasma lecithin-cholesterol acyltransferase (LCAT) (Brumlik \& Buckley, 1996), but shows high homology to A. bydrophila H3 lipase and JMP636 Apl-1 lipase, it is likely that the Lip protein is more closely related to the latter two lipases. However, there are considerable differences in enzyme properties among the three lipases. Apl-1 lipase possesses phospholipase C activity (Ingham \& Pemberton, 1995), while no phospholipase activity was detected in Lip protein. Likewise, molecular sizes, optimum $\mathrm{pH}$, optimum temperature, thermal stability and, especially, substrate specificity of Lip protein and $\mathrm{H} 3$ lipase are distinct. The $\mathrm{H} 3$ lipase described by Anguita et al. (1993) showed high thermostability, and its lipolytic activities were observed with $p$-nitrophenyl derivatives with chain lengths in the range $C_{4}$ to $C_{10}$ as substrates and with triacylglycerols with lengths in the range $\mathrm{C}_{4}$ to $\mathrm{C}_{8}$. The Lip protein $\mathrm{pI}$ value $(10 \cdot 36)$ was higher than that of $\mathrm{H} 3$ lipase and those of known microbial lipases (Sugiura, 1984; Dartois et al., 1992). In addition, our observation that cloned Lip protein was primarily localized to a membrane-bound site in E. coli differs from the findings of Anguita et al. (1993). These authors observed that the $\mathrm{H} 3$ lipase gene product was present in the periplasmic space in E. coli. Based on the amino acid alignment shown, Lip protein contains an additional 100 amino acids at the C-terminal end which are not present in $\mathrm{H} 3$ lipase and lacks 37 amino acid residues that correspond to Gly-380 to Arg-416 in H3 lipase. The different enzyme properties described above may result from these major differences of amino acid sequence between the two enzymes. Clearly, further experiments are required to clarify this point.

\section{ACKNOWLEDGEMENTS}

This work was supported by research grant NSC84-2331B006-024 from the National Science Council, Taiwan, Republic of China.

\section{REFERENCES}

Agger, W. A., McCormick, J. D. \& Gurwith, M. J. (1985). Clinical and microbiological features of Aeromonas hydrophila-associated diarrhea. J Clin Microbiol 21, 909-913.

Altwegg, M. \& Geiss, H. K. (1989). Aeromonas as a human pathogen. Crit Rev Microbiol 16, 253-286.
Anguita, J., Rodriguez Aparicio, L. B. \& Naharro, G. (1993). Purification, gene cloning, amino acid sequence analysis, and expression of an extracellular lipase from an Aeromonas bydrophila human isolate. Appl Environ Microbiol 59, 2411-2417.

Antonian, E. (1988). Recent advances in the purification, characterization and structure determination of lipases. Lipids 23, 1101-1106.

Asao, T., Kinoshita, Y., Kozaki, S., Uemura, T. \& Sakaguchi, G. (1984). Purification and some properties of Aeromonas bydrophila hemolysin. Infect Immun 46, 122-127.

Beggs, J. D. (1978). Transformation of yeast by a replicating hybrid plasmid. Nature 275, 104-109.

Bolivar, F., Rodriguez, R. L., Greene, P. J., Betlach, M. C., Heyneker, H. L. \& Boyer, H. W. (1977). Construction and characterization of new cloning vehicles. II. A multipurpose cloning system. Gene 2, 95-113.

Brumlik, M. J. \& Buckley, J. M. (1996). Identification of the catalytic triad of the lipase/acyltransferase from Aeromonas bydrophila. J Bacteriol 178, 2060-2064.

Burke, V., Robinson, J., Berry, R. J. \& Gracey, M. (1981). Detection of enterotoxins of Aeromonas bydrophila by a suckling-mouse test. J Med Microbiol 14, 401-408.

Buttke, T. M. \& Cuchens, M. A. (1984). Inhibition of lymphocyte proliferation by free fatty acids. II. Toxicity of stearic acid towards phytohaemagglutinin-activated T cells. Immunology 53, 507-514.

Chang, M. C., Chang, C. C. \& Chang, J. C. (1992a). Cloning of a creatinase gene from Pseudomonas putida in Escherichia coli by using an indicator plate. Appl Environ Microbiol 58, 3437-3440.

Chang, M. C., Chang, S. Y., Chen, S. L. \& Chuang, S. M. (1992b). Cloning and expression in Escherichia coli of the gene encoding an extracellular deoxyribonuclease (DNase) from Aeromonas bydrophila. Gene 122, 175-180.

Chang, M. C., Chang, J. C. \& Chen, J. P. (1993). Cloning and nucleotide sequence of an extracellular $\alpha$-amylase gene from Aeromonas hydrophila MCC-1. J Gen Microbiol 139, 3215-3223.

Dartois, V., Baulard, A., Schanck, K. \& Colson, C. (1992). Cloning, nucleotide sequence and expression in Escherichia coli of a lipase gene from Bacillus subtilis 168. Biochim Biophys Acta 1131, 253-260.

Doagan, G. \& Kehoe, M. (1984). The minicell system as a method for studying expression from plasmid DNA. Methods Microbiol $17,233-258$

Dodd, H. N. \& Pemberton, J. M. (1996). Cloning, sequencing, and characterization of the $n u c H$ gene encoding an extracellular nuclease from Aeromonas hydrophila JMP636. J Bacteriol 178, 3926-3933.

Dooley, J. S., McCubbin, W. D., Kay, C. M. \& Trust, T. J. (1988). Isolation and biochemical characterization of the $S$-layer protein from a pathogenic Aeromonas hydrophila strain. J Bacteriol 170, 2631-2638.

Eftimiadi, C., Buzzi, E., Tonetti, M., Buffa, P., Buffa, D., Van Steenbergen, M. T., de Graaff, J. \& Botta, G. A. (1987). Shortchain fatty acids produced by anaerobic bacteria alter the physiological responses of human neutrophils to chemotactic peptide. J Infect Dis 14, 43-53.

d'Enfert, C., Ryter, A. \& Pugsley, A. P. (1987). Cloning and expression in Escherichia coli of the Klebsiella pneumoniae genes for production, surface localization and secretion of the lipoprotein pullulanase. EMBO J 6, 3531-3538.

Faustinella, F., Smith, L. C., Semenkovich, C. F. \& Chan, L. (1991). 
Structural and functional roles of highly conserved serines in human lipoprotein lipase. J Biol Chem 266, 9481-9485.

Favre, D., Ngai, P. K. \& Timmis, K. N. (1993). Relatedness of a periplasmic, broad-specificity $\mathrm{RNase}$ from Aeromonas bydrophila to RNase I of Escherichia coli and to a family of eukaryotic RNases. J Bacteriol 175, 3710-3722.

Figura, N., Marri, L., Verdiani, S., Ceccherini, C. \& Barberi, A. (1986). Prevalence, species differentiation, and toxigenicity of Aeromonas strains in cases of childhood gastroenteritis and in controls. J Clin Microbiol 23, 595-599.

Filip, C., Fletcher, G., Wulff, J. L. \& Earhart, C. F. (1973). Solubilization of the cytoplasmic membrane of Escherichia coli by the ionic detergent sodium-lauryl sarcosinate. J Bacteriol 115, $717-722$.

Gennity, J. M., Kim, H. \& Inouye, M. (1992). Structural determinants in addition to the amino-terminal sorting sequence influence membrane localization of Escherichia coli lipoproteins. J Bacteriol 174, 2095-2101.

Gobius, K. S. \& Pemberton, J. M. (1988). Molecular cloning, characterization, and nucleotide sequence of an extracellular amylase gene from Aeromonas bydrophila. J Bacteriol 170, 1325-1332.

Harwood, J. (1989). The versatility of lipases for industrial uses. Trends Biochem Sci 14, 125-126.

Hedstrom, S. A. \& Nisson, P. (1975). Lipolytic activity of Staphylococcus aureus strains from cases of human chronic osteomyelitis and other infections. Acta Pathol Microbiol Scand Sect B 83, 285-292.

von Heijne, G. (1986). A new method for predicting signal sequence cleavage sites. Nucleic Acids Res 14, 4683-4690.

Hilton, S., McCubbin, W. D., Kay, C. M. \& Buckley, J. M. (1990). Purification and spectral study of a microbial fatty acyltransferase: activation by limited proteolysis. Biochemistry 29, 9072-9078.

Ho, A. S., Mietzner, T. A., Smith, A. J. \& Schoolnik, G. K. (1990). The pili of Aeromonas hydrophila: identification of an environmentally regulated 'mini pilin'. J Exp Med 172, 795-806.

Howard, S. P., Garland, W. J., Green, M. J. \& Buckley, J. T. (1987). Nucleotide sequence of the gene for the hole-forming toxin aerolysin of Aeromonas bydrophila. J Bacteriol 169, 2869-2871.

Huang, J. \& Schell, M. (1992). Role of the two-component leader sequence and mature amino acid sequence in extracellular export of endoglucanase EGL from Pseudomonas solanacearum. J Bacteriol 174, 1314-1323.

Ikemura, T. \& Ozeki, H. (1982). Coden usage and transfer RNA contents: organism-specific codon-choice patterns in reference to the isoacceptor contents. Cold Spring Harbor Symp Quant Biol 47, 1087-1097.

Ingham, A. B. \& Pemberton, J. M. (1995). A lipase of Aeromonas bydropbila showing nonhemolytic phospholipase $\mathrm{C}$ activity. Curr Microbiol 31, 28-33.

Innis, M. A. \& Gelfand, D. H. (1990). Optimization of PCRs. In PCR Protocols: a Guide to Methods and Applications, pp. 3-12. Edited by M. A. Innis, D. H. Gelfand, J. J. Sninsky \& T. J. White. San Diego, CA: Academic Press.

Janda, J. M. \& Duffey, P. S. (1988). Mesophilic aeromonads in human disease: current taxonomy, laboratory identification, and infectious disease spectrum. Rev Infect Dis 10, 980-997.

Johnson, W. M. \& Lior, H. (1981). Cytotoxicity and suckling mouse reactivity of Aeromonas bydrophila isolated from human sources. Can J Microbiol 27, 1019-1027.
Ko, W. C. \& Chuang, Y. C. (1995). Aeromonas bacteremia : review of 59 episodes. Clin Infect Dis 20, 1298-1304.

Kohli, J. \& Grosjean, H. (1981). Usage of the three termination codons: compilation and analysis of the known eukaryotic and prokaryotic translation termination sequences. Mol Gen Genet $182,430-439$.

Kuijper, E. J., Bol, P., Peeters, M. F., Steigerwalt, A. G., Zanen, H. C. \& Brenner, D. J. (1989). Clinical and epidemiologic aspects of members of Aeromonas DNA hybridization groups isolated from human feces. J Clin Microbiol 27, 1531-1537.

Laemmli, U. K. (1970). Cleavage of structural proteins during the assembly of the head of bacteriophage T4. Nature 227, 680-685.

Lawson, M. A., Burke, V. \& Chang, B. J. (1985). Invasion of Hep2 cells by fecal isolates of Aeromonas hydrophila. Infect Immun 47, 680-683.

Lee, Y. P., Chung, G. H. \& Rhee, J. S. (1993). Purification and characterization of Pseudomonas fluorescens SIK W1 lipase expressed in Escherichia coli. Biochim Biophys Acta 1169, $156-164$.

Leung, K.-Y. \& Stevenson, R. M. W. (1988). Characteristics and distribution of extracellular proteases from Aeromonas bydrophila. J Gen Microbiol 134, 151-160.

McGavin, M. J., Forsberg, C. W., Crosby, B., Bell, A. W., Dignard, D. \& Thomas, D. Y. (1989). Structure of the cel-3 gene from Fibrobacter succinogenes $\mathrm{S} 85$ and characteristics of the encoded gene product, endoglucanase 3. J Bacteriol 171, 5587-5595.

Mikhail, I. A., Fox, E., Haberberger, R. L., Jr, Ahmed, M. H. \& Abbatte, E. A. (1990). Epidemiology of bacterial pathogens associated with infectious diarrhea in Djibouti. J Clin Microbiol 28, 956-961.

Namdari, H. \& Bottone, E. J. (1990). Microbiologic and clinical evidence supporting the role of Aeromonas caviae as a pediatric enteric pathogen. J Clin Microbiol 28, 837-840.

Oudega, B., Clark, D., Stegehuis, F., Majoor, M. J. \& Luirink, J. (1993). A lipoprotein signal peptide plus a cysteine residue at the amino-terminal end of the periplasmic protein beta-lactamase is sufficient for its lipid modification, processing and membrane localization in Escherichia coli. FEMS Microbiol Lett 108, 353-359.

Rollof, J., Braconier, J. H., Soderstrom, C. \& Nilsson-ehle, P. (1988). Interference of Staphylococcus aureus lipase with human granulocyte function. Eur J Clin Microbiol Infect Dis 7, 505-510.

Rose, J. M., Houston, C. W., Coppenhaver, D. H., Dixon, J. D. \& Kurosky, A. (1989). Purification and chemical characterization of a cholera toxin-cross-reactive cytolytic enterotoxin produced by a human isolate of Aeromonas bydrophila. Infect Immun 57, 1165-1169.

Sambrook, J., Fritsch, E. F. \& Maniatis, T. (1989). Molecular Cloning: a Laboratory Manual, 2nd edn. Cold Spring Harbor, NY : Cold Spring Harbor Laboratory.

Sanger, F., Nicklen, S. \& Coulson, A. R. (1977). DNA sequencing with chain-terminating inhibitors. Proc Natl Acad Sci USA 74, 5463-5467.

Sankaran, K. \& Wu, H. C. (1994). Lipid modification of bacterial prolipoprotein. J Biol Chem 269, 19701-19706.

Shine, J. \& Dalgarno, L. (1974). The $3^{\prime}$-terminal sequence of Escherichia coli $16 \mathrm{~S}$ ribosomal RNA : complementarity to nonsense triplets and ribosome binding sites. Proc Natl Acad Sci USA $71,1342-1346$.

Spok, A., Stubenrauch, G., Schörgendorfer, K. \& Schwab, H. 
(1991). Molecular cloning and sequencing of a pectinesterase gene from Pseudomonas solanacearum. J Gen Microbiol 137, 131-140.

Sugiura, M. (1984). Bacterial lipases. In Lipases, pp. 505-523. Edited by B. Borgstrom \& H. L. Brockman. Amsterdam : Elsevier.

Thornton, J., Howard, S. P. \& Buckley, J. T. (1988). Molecular cloning of a phospholipid-cholesterol acyltransferase from Aeromonas hydrophila: sequence homologies with lecithin-cholesterol acyltransferase and other lipases. Biochim Biophys Acta 959, 153-159.

van Doorn, J., Oudega, B., Mool, F. R. \& de Graaf, F. K. (1982). Subcellular localization of polypeptides involved in the biosynthesis of K88ab fimbriae. FEMS Microbiol Lett 13, 99-104.
Vieira, J. \& Messing, J. (1982). The pUC plasmids, an M13mp7derived system for insertion mutagenesis and sequencing with synthetic universal primers. Gene 19, 259-268.

Wu, H. C. \& Tokunaga, M. (1986). Biogenesis of lipoproteins in bacteria. Curr Top Microbiol Immunol 125, 127-157.

Yanisch-Perron, C., Vieira, J. \& Messing, J. (1985). Improved M13 phage cloning vectors and host strains: nucleotide sequences of the M13mp18 and pUC19 vectors. Gene 33, 103-119.

Received 23 July 1996; revised 10 October 1996; accepted 21 October 1996. 